\title{
First Eugereonidae (Insecta: Palaeodictyoptera) from the Pennsylvanian (Late Carboniferous) of the Piesberg site near Osnabrück, Germany
}

\author{
Carsten Brauckmann ${ }^{1} \cdot$ Karl Josef Herd ${ }^{2}$. Angelika Leipner ${ }^{3}$
}

Received: 5 February 2021 / Accepted: 31 July 2021

(c) The Author(s) 2021

\begin{abstract}
Sandiella herbigi sp. nov. is the first record of the family Eugereonidae Handlirsch, 1906 (Insecta: Palaeodictyoptera) in the Pennsylvanian (Late Carboniferous: Westphalian D) sequence of the Piesberg quarry near Osnabrück, Lower Saxony, Germany. It is represented by a single fragment of a mesothoracic wing with the typical coarse reticulation in this family. The species is mainly characterized by the following features: (i) the shape of the mesothoracic wing is extremely narrow, (ii) the posterior subcostal vein is ending before the wing apex, (iii) all the main veins show a typical bend close to the posterior margin. The new wing is the second most ancient record of the Eugereonidae.
\end{abstract}

Keywords Sandiella herbigi sp. nov. · Eugereonidae · Pennsylvanian (Late Carboniferous) · Piesberg · Germany

\section{Introduction}

The large quarry of the Piesberg near Osnabrück, Lower Saxony, is mainly known for its rich and unusually wellpreserved fossil flora of Pennsylvanian (Late Carboniferous: Moscovian, Westphalian D/Asturian) age. But, beside the former brickyard quarry of Hagen-Vorhalle with its Namurian insects, arachnids etc. (Brauckmann 1988; Zessin et al. 2019), it is also an important locality for fossil insects as well as for insect nymphs and larvae (Brauckmann and Herd 2002, 2005, 2007; Zessin 2006; Béthoux and Herd 2009; Aristov 2015; Brauckmann et al. 2009, 2016; Wrede et al.

Handling Editor: Sven Hartenfels.

Carsten Brauckmann

Carsten.Brauckmann@tu-clausthal.de

Karl Josef Herd

herd.carlo@t-online.de

Angelika Leipner

Leipner@osnabrueck.de

1 Institut für Geologie und Paläontologie, TU Clausthal (Clausthal University of Technology), Leibnizstraße 10, 38678 Clausthal-Zellerfeld, Germany

2 Am Gartenfeld 66, 51519 Odenthal-Holz, Germany

3 Museum am Schölerberg, Klaus-Strick-Weg 10, 49082 Osnabrück, Germany
2019; Pecharová et al. 2020; Haug et al. 2013; Nel et al. 2013; Hörnig et al. 2014; Kiesmüller et al. 2019; Dvořák et al. 2021; Zessin et al. 2021). Some other arthropod groups as for example Xiphosura (Haug et al. 2012), Scorpiones (Dunlop et al. 2008), Trigonotarbida (Rößler 1998), Arthropleurida (Kraus and Brauckmann 2003) and Pygocephalomorpha (Pazinato et al. 2019) have already been reported from this locality.

During the last 3 decades more than 1300 remains of insects and insect nymphs were collected, most of them preserved as isolated wings or wing fragments. The larger number of these fossils was collected by the amateur collector Michael Sowiak (Glandorf near Osnabrück) and one of the authors (A.L.). Only a smaller part has already been described, and the research is still continuing.

Due to the large number of new taxa and the high diversity, the Piesberg site is one of the most important localities for Pennsylvanian (Late Carboniferous) insects which in the meantime received international scientific interest.

\section{Materials and methods}

The analytical drawing of the specimen was prepared from photographs by one of the authors (A.L.) using the free painting program paint.net. The photograph was taken using a Canon EOS 350 D camera with Objective Canon 
EFS $18-55 \mathrm{~mm}$ and EFS $60 \mathrm{~mm}$, using a copy stand with daylight lamps. Diaphragm was 18 with different exposure times.

As already used in earlier papers on Palaeodictyoptera from the Piesberg site (for example, Brauckmann et al. 2016), the terminology of the wing venation follows Kukalová-Peck and Richardson (1983):

$\mathrm{C}^{+}=$Costa $; \mathrm{ScP}^{-}=$Subcostal posterior; $\mathrm{RA}^{+}=$Radius anterior; $\mathrm{RP}^{-}=$Radius posterior; $\mathrm{MA}^{+}=$Media anterior; $\mathrm{MP}^{-}=$Media posterior; $\mathrm{CuA}^{+}=\mathrm{Cubitus}$ anterior; $\mathrm{CuP}^{-}=$Cubitus posterior.

\section{Geological setting}

The specimen described was collected from layer 4 of freshwater lake sediments discovered in 2018 between the seams "Mittel" and "Johannisstein" and are thus of middle Westphalian D/Asturian (Pennsylvanian, Late Carboniferous: Moscovian) age. This new deposit has yielded several meso- and xerophyllous plants which are normally not preserved in Pennsylvanian coal-bearing strata and an accompanying fauna which differs from the other Piesberg fossil bearing strata in a shift of occurrences and some new taxa for this locality (Leipner 2019; Leipner and Chellouche 2019; Wrede et al. 2019). Further details concerning the geology and stratigraphy, as well as the fossil content, of the Pennsylvanian (Late Carboniferous) sequence in the Osnabrück region has been compiled by Köwing and Rabitz (2005), Brauckmann and Herd (2002), Dunlop et al. (2008), and Haug et al. (2013) which we refer to.

\section{Systematic palaeontology}

Order Palaeodictyoptera Goldenberg, 1877 (=Dictyoneurida sensu Sinitshenkova 2002)

Remarks. The higher classification of this order is still discussed controversially.

Family Eugereonidae Handlirsch, 1906

Diagnosis. Carpenter (1992: 31).

Further details. Carpenter (1964, 1970); Kukalová (1969).

Genera and species included. Eugereon boeckingi Dohrn, 1866 (type species), Cisuralian (Lower Permian: Autunian), Schwarzenbach near Birkenfeld, Saar-Nahe Basin, Germany (further details: Brauckmann 2007: 177);
Dictyoptilus renaulti Brongniart, 1893 (type species), Pennsylvanian (Late Carboniferous: Stephanian), Commentry, France;

D. peromapteroides (Meunier, 1908), Pennsylvanian (Late Carboniferous: Stephanian), Commentry, France;

D. sepultus (Meunier, 1910), Pennsylvanian (Late Carboniferous: Stephanian), Commentry, France;

Peromaptera filholi Brongniart, 1893 (type species), Pennsylvanian (Late Carboniferous: Stephanian), Commentry, France;

Sandiella readi Carpenter, 1970 (type species), Pennsylvanian (Late Carboniferous; Sandia Formation), Sandia Mountains, eastern suburbs of the city of Santa Fe, New Mexico, USA (the terrestrially influenced higher sequence of the Sandia Formation can approximately be allocated to the Westphalian $\mathrm{C}=$ Bolsovian, Moscovian (Schneider et al. 2019); thus Sandiella readi is clearly the most ancient member of the Eugereonidae);

S. herbigi sp. nov., Pennsylvanian (Late Carboniferous: Westphalian D/Asturian), Piesberg near Osnabrück, Germany;

Valdeania medeirosi Teixeira, 1941 (type species), Pennsylvanian (Late Carboniferous: Stephanian), Valdeão near Valongo E Porto, Portugal.

A further distal fragment of a wing from the Meisenheim Formation M4 (Autunian) of Sitters (Saar-Nahe Basin) was tentatively assigned to the Eugereonidae by Poschmann and Schindler (2004), but not yet described in detail.

Remarks. The Eugereonidae can easily be recognized by the strong differences in the shape of their mesothoracic (long and narrow) and metathoracic wings (distinctly shorter) as well as by the crossveins forming a dense and rather coarse reticulation. Only both the Sandiella species are of Westphalian age. All the other Eugereonidae are of younger Stephanian and Autunian age.

As shown by the preserved head and body structures of Eugereon boeckingi, the Eugereonidae share typical morphological characters with other Palaeodictyoptera, as for example, (i) a small head with a slender haustellate beak and inconspicuous leg-like maxillary palpi, (ii) a narrow prothorax with a pair of small prothoracic wings, and (iii) non-overlapping mesothoracic and metathoracic wings. The abdomen and the cerci are still not known, but due to the proportions of the thorax, we should expect a rather short abdomen, and similar to other Palaeodictyoptera, a pair of rather long and delicately setaceous cerci with a great number of segments. The haustellate beak indicates that the animals were feeding on spores or vegetable juices. With a wingspan between 12 and $32 \mathrm{~cm}$, the Eugereonidae are mediumsized to larger representatives of the Palaeodictyoptera. 
Genus Sandiella Carpenter, 1970

Type species. Sandiella readi Carpenter, 1970, Pennsylvanian (Late Carboniferous: Westphalian B, late Bashkirian to early Moscovian), Sandia Mountains, New Mexico, USA.

Diagnosis. Carpenter (1970: 405; 1992: 31, modified). Similar to Dictyoptilus but with a coarser reticulation of crossveins and without rows of crossveins between RA and RP; Sc ending well before apex of wing.
Species included. Sandiella readi Carpenter, 1970 (Fig. 1) and $S$. herbigi sp. nov. (Fig. 2).

\section{Sandiella herbigi sp. nov.}

Figure 2

Holotype. Wing no. Pal 1670, distal fragment of right wing, collected by one of the authors (AL), deposited in the Museum am Schölerberg, Osnabrück.
Fig. 1 Sandiella readi Carpenter, 1970, mesothoracic wing (for comparison), Pennsylvanian (Late Carboniferous; Sandia Formation, Westphalian C), Sandia Mountains, eastern suburbs of the city of Santa Fe, New Mexico, USA ( modified from Carpenter 1970). Scale bar $=10 \mathrm{~mm}$
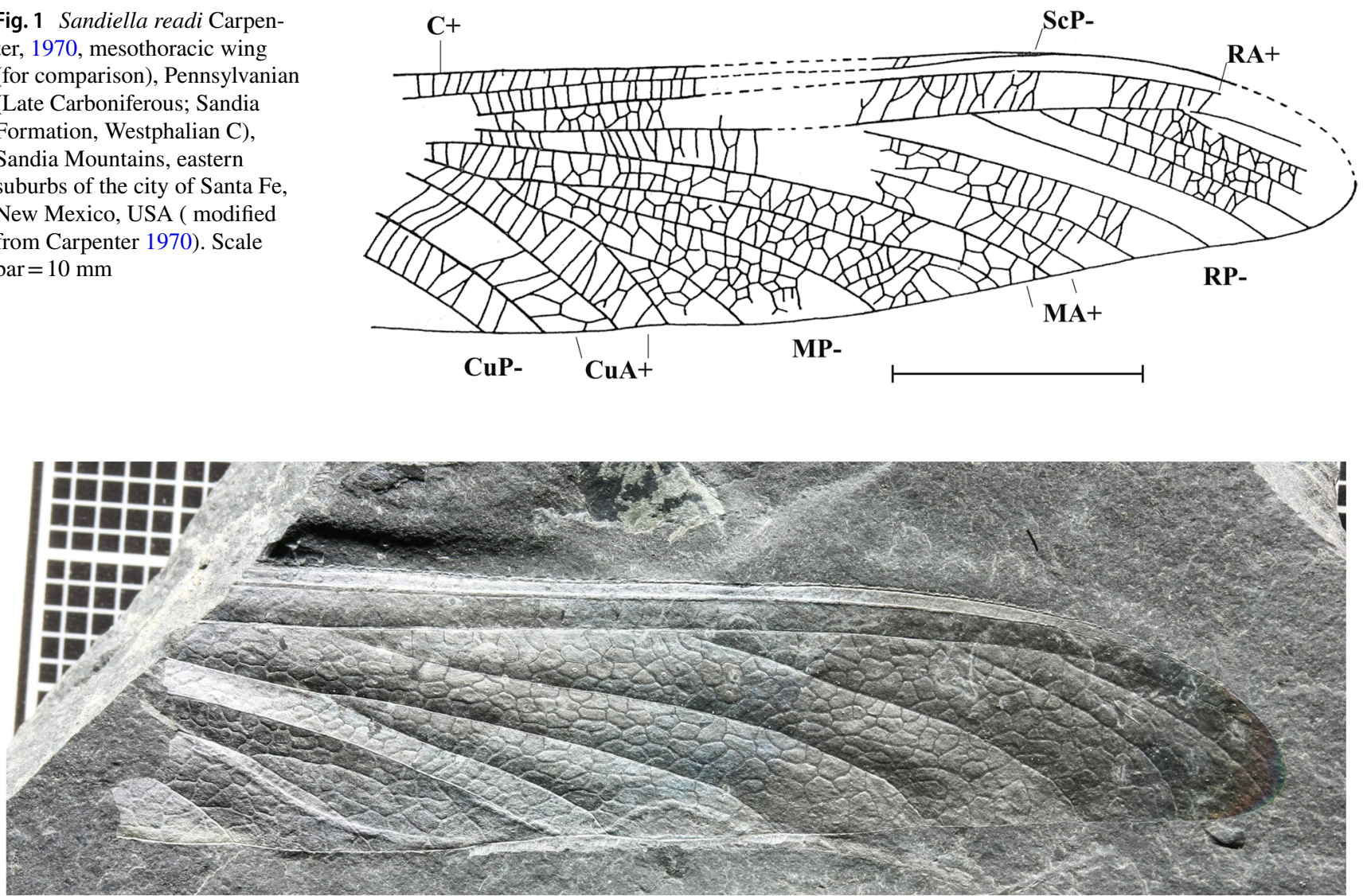

a

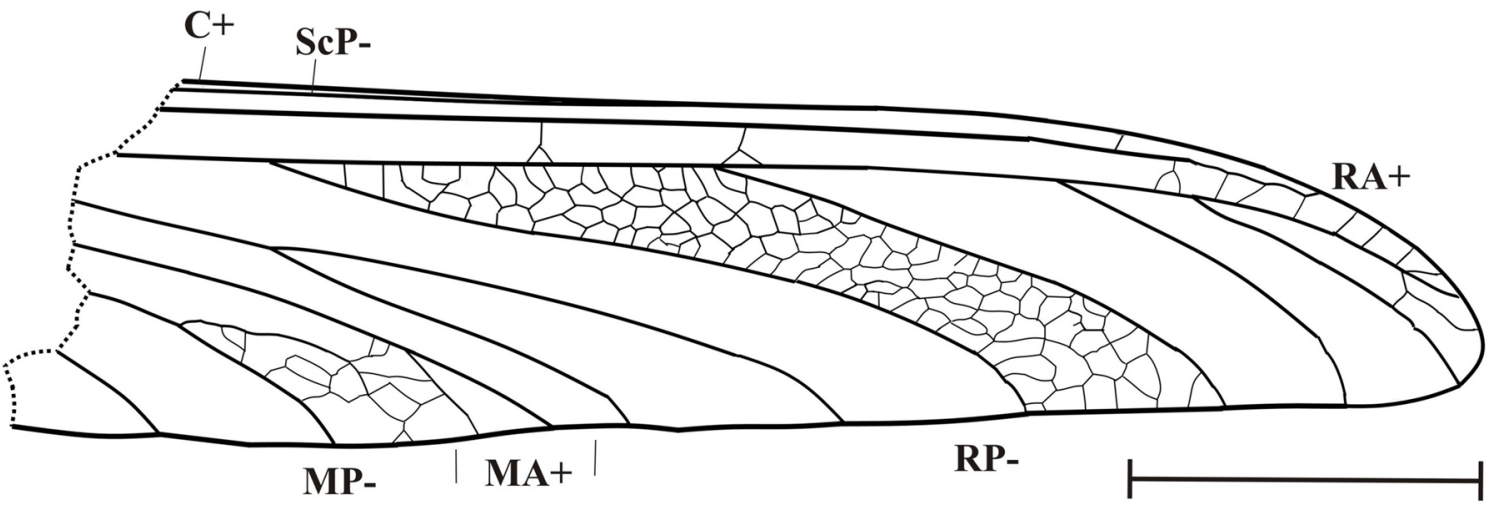

Fig. 2 Sandiella herbigi sp. nov., Pennsylvanian (Late Carboniferous): middle Westphalian D/Asturian, Piesberg near Osnabrück, Lower Saxony, Germany. a Photograph of holotype Pal 1670, distal fragment of right mesothoracic wing. b Drawing of holotype. Scale bar $=10 \mathrm{~mm}$ 
Type locality and type stratum. Pennsylvanian (Late Carboniferous): middle Westphalian D/Asturian: lake deposit between seam "Mittel" and seam "Johannisstein", Piesberg near Osnabrück, Germany.

Etymology. In honour of Professor Dr. Hans-Georg Herbig, Cologne.

Diagnosis. Wing with an estimated total length of about $90 \mathrm{~mm}$, and an estimated maximum width of $12 \mathrm{~mm}$, with the following main characters: (i) mesothoracic wing extremely long and slender; (ii) $\mathrm{ScP}-$ ending in $\mathrm{C}+$ (or dissolving) far before wing apex; (iii) all preserved main veins with a marked bend close to posterior margin; (iv) crossveins rather coarse, densely reticulated.

Description. Distal fragment of long and extremely slender mesothoracic wing, preserved from apex to MP2-; preserved length $=41 \mathrm{~mm}$ (estimated total length $=90 \mathrm{~mm}$ ), maximum width $=10.5 \mathrm{~mm}$; anterior margin almost straight, apex narrowly rounded, slightly shifted in posterior direction; posterior margin nearly straight, but very slightly undulated (bend inwards at MA+ and MP2-); as far as preserved, $\mathrm{C}+, \mathrm{ScP}-$ and RA+ sub-parallel, very close to each other; $\mathrm{ScP}-$ short, ending in $\mathrm{C}+$ (or dissolving) far before apex (similar to Sandiella readi); $\mathrm{RA}+$ simple, ending in $\mathrm{C}+$ near to apex; inter-radial area (= area between $\mathrm{RA}+$ and $\mathrm{RP}-$ ) very narrow; $\mathrm{RP}-$ with 7 terminal branches, only the proximal branch bifurcate, distances between each branch of RPfar; separation of RA+ and RP- not preserved, evidently in proximal part of wing; MA+ simple, ending about $25 \mathrm{~mm}$ from wing apex into posterior margin (distinctly farther from apex than in $S$. readi); MP- with at least 2 branches; all preserved main veins with a marked bend close to posterior margin; crossveins rather coarse, forming a very dense archedictyon.

Comparison. The general characters of Sandiella herbigi sp. nov. (long and slender mesothoracic wing, rather simple main venation, cross veins rather coarse, forming a dense archedictyon) are typical for the Eugereonidae.

The new species shares with Sandiella readi (i) the short $\mathrm{ScP}-$ and (ii) the rather coarse archedictyon and is, therefore, here assigned to Sandiella. S. herbigi sp. nov. differs from the stratigraphically older $S$. readi mainly by its slightly larger dimensions and the still more slender shape. Further differences are (i) the narrower inter-radial area (=area between RA+ and RP-), (ii) the larger distances between each branch of RP- and (iii) the distinctly more proximal position of the ending of MA+ into the posterior margin in S. herbigi (Table 1).
Table 1 Dimensions of the wings of the Eugereonidae

\begin{tabular}{|c|c|c|c|}
\hline \multirow[t]{3}{*}{ Species } & \multicolumn{2}{|l|}{ Length } & \multirow{2}{*}{$\begin{array}{l}\text { Width }(\mathrm{mm}) \\
\text { Fore wing }\end{array}$} \\
\hline & Fore wing & & \\
\hline & Estimated & Preserved & Preserved \\
\hline Eugereon boeckingi & 48 & 80 & $(32)$ \\
\hline Dictyoptilus renaulti & 32 & $(160)$ & 19 \\
\hline Dictyoptilus peromapteroides & 114 & 114 & 22 \\
\hline Dictyoptilus sepultus & 106 & 106 & 20 \\
\hline Peromaptera filholi & 60 & 65 & 13 \\
\hline Sandiella readi & 40 & 60 & 10 \\
\hline Sandiella herbigi sp. nov. & 41 & 90 & 10.5 \\
\hline Valdeania medeirosi & 47 & 64 & 9 \\
\hline
\end{tabular}

The species of Dictyoptilus differ mainly by their distinctly longer $\mathrm{ScP}-$, the apparently less coarse archedictyon and their larger dimensions.

Peromaptera filholi differs by the slightly broader shape, the markedly undulated posterior margin and the less dense archedictyon.

Beyond the small head with a slender haustellate beak, the prothorax with legs and small prothoracic wings, as well as remains of the mesothorax and metathorax, in Eugereon boeckingi only the basal parts of the wings are preserved. Therefore, a more detailed comparison is not possible. With an estimated length of the mesothoracic wing of about $75-80 \mathrm{~mm}$, it is a little bit smaller than Sandiella herbigi.

Valdeania medeirosi shows the typical wing proportions of the Eugereonidae. As far as one can judge from the tectonic distortion, it seems to differ from Sandiella herbigi by the much more curved main veins and the less number of branches of RP.

\section{Conclusions}

The new species enlarges the regional and stratigraphical range of the palaeodictyopteran insect genus Sandiella and fills a gap within the record of the Eugereonidae.

Acknowledgements Dr Elke Gröning (Clausthal-Zellerfeld, Germany) helped to improve the manuscript. Dr Jarmila Kukalová-Peck (Ottawa, Canada) is thanked for her repeated help. We also thank the GP Papenburg company for their permission for palaeontological field work in their quarry and technical assistance, the creators of the free painting program paint.net, Dr Andrew J. Ross (Edinburgh) and an anonymous reviewer for their helpful comments, and in particular Dr Mike Reich and Professor Dr Michael Amler for editorial support. Without the enormous field work of Michael Sowiak, the discovery of the described insect wing would not have been possible to achieve in time. 
Funding Open Access funding enabled and organized by Projekt DEAL.

Open Access This article is licensed under a Creative Commons Attribution 4.0 International License, which permits use, sharing, adaptation, distribution and reproduction in any medium or format, as long as you give appropriate credit to the original author(s) and the source, provide a link to the Creative Commons licence, and indicate if changes were made. The images or other third party material in this article are included in the article's Creative Commons licence, unless indicated otherwise in a credit line to the material. If material is not included in the article's Creative Commons licence and your intended use is not permitted by statutory regulation or exceeds the permitted use, you will need to obtain permission directly from the copyright holder. To view a copy of this licence, visit http://creativecommons.org/licenses/by/4.0/.

\section{References}

Aristov, D.S. 2015. Classification of the order Eoblattida (Insecta, Blattidea) with description of new Taxa. Far Eastern Entomologist 301: 1-56.

Béthoux, O., and K.J. Herd. 2009. Discovery of an enigmatic and gigantic Pennsylvanian Archaeorthoptera. Journal of Orthoptera Research 18(1): 23-28.

Brauckmann, C. 1988. Hagen-Vorhalle, a new important Namurian Insecta-bearing locality (Upper Carboniferous; FR Germany). Entomologia Generalis 14(1): 73-79.

Brauckmann, C. 2007. Die Insekten im Permokarbon des Saar-NaheBeckens. In Kohlesümpfe, Seen und Halbwüsten. Dokumente einer rund 300 Millionen Jahre alten Lebewelt zwischen Saarbrücken und Mainz, eds. T. Schindler and U.H.J. Heidtke. Pollichia Sonderveröffentlichungen 10 170-196.

Brauckmann, C., and K.J. Herd. 2002. Insekten-Funde aus dem Westfalium D (Ober-Karbon) des Piesberges bei Osnabrück (Deutschland). Osnabrücker Naturwissenschaftliche Mitteilungen 28: 27-69.

Brauckmann, C., and K.J. Herd. 2005. Insekten-Funde aus dem Westfalium D (Ober-Karbon) des Piesberges bei Osnabrück (Deutschland), Teil 2 Neoptera. Osnabrücker Naturwissenschaftliche Mitteilungen 30(31): 19-65.

Brauckmann, C., and K.J. Herd. 2007. A subcircular insect wing from the Late Carboniferous of Osnabrück, Germany. Clausthaler Geowissenschaften 6: 79-85.

Brauckmann, C., K.J. Herd, and A. Leipner. 2009. Insekten-Funde aus dem Westfalium D (Ober-Karbon) des Piesberges bei Osnabrück. Osnabrücker Naturwissenschaftliche Mitteilungen 35: 5-30.

Brauckmann, C., K.J. Herd, and A. Leipner. 2016. The Late Carboniferous Mazonopterum (Insecta, Palaeodictyoptera, Homoiopteridae) in Central Europe. Clausthaler Geowissenschaften 10: 1-10.

Brongniart, C. 1893. Recherches pour server à l'histoire des insects fossiles des temps premières, précédées d'une étude sur la nervation des ailes des insectes, 1-495. Thèse présentée à Faculté des Sciences de Paris.

Carpenter, F.M. 1964. Studies on Carboniferous insects of Commentry, France: Part VI. The genus Dictyoptilus (Palaeodictyoptera). Psyche 71(3): 104-116.

Carpenter, F.M. 1970. Fossil insects from New Mexico. Psyche 77: 400-412.

Carpenter, F.M. 1992. Superclass Hexapoda. In Treatise on Invertebrate Paleontology, Part R, Arthropoda 4(3-4), ed. R.L. Kaesler, 1-655. Boulder, Colo.: The Geological Society of America, and Lawrence, Kans.: The University of Kansas Press.

Dohrn, A. 1866. Eugereon boeckingi, eine neue Insectenform aus dem Todtliegenden. Palaeontographica 13: 333-340.
Dunlop, J.A., C. Brauckmann, and H. Steur. 2008. A Late Carboniferous fossil scorpion from Piesberg, near Osnabrück, Germany. Fossil Record 11(1): 25-32.

Dvořák, T., M. Pecharová, A. Leipner, A. Nel, and J. Prokop. 2021. New archaeorthopteran insects from the Pennsylvanian of Piesberg reveal unexpected mosaic of morphological traits and coloration pattern of the tegmina. Historical Biology. https://doi.org/10. 1080/08912963.2020.1867127.

Goldenberg, F. 1877. Fauna Saraepontana Fossilis. Die fossilen Thiere aus der Steinkohlenformation von Saarbrücken, Part II, 1-54. Saarbrücken: Möllinger.

Handlirsch, A. 1906-1908. Die fossilen Insekten und die Phylogenie der rezenten Formen. Ein Handbuch für Paläontologen und Zoologen, 1-1433. Leipzig: Engelmann.

Haug, J.T., A. Leipner, T. Wappler, and C. Haug. 2013. Palaeozoic insect nymphs: New finds from the Piesberg quarry (Upper Carboniferous, Germany). Bulletin of Geosciences 88: 779-791.

Haug, C., P. van Roy, A. Leipner, P. Funch, D.M. Rudkin, L. Schöllmann, and J.T. Haug. 2012. A holomorph approach to xiphosuran evolution-A case study on the ontogeny of Euproops. Development Genes and Evolution 222(5): 253-268.

Hörnig, M.K., C. Haug, K.J. Herd, and J.T. Haug. 2014. New insights into dictyopteran early development: Smallest Palaeozoic roachoid nymph found so far. Palaeodiversity 7: 159-165.

Kiesmüller, C., M.K. Hörnig, A. Leipner, and J.T. Haug. 2019. Palaeozoic palaeodictyopteran insect nymphs with prominent ovipositors from a new locality. Bulletin of Geosciences 94(1): 23-40.

Köwing, K., and A. Rabitz. 2005. 4.1.3. Osnabrücker Karbon. In Stratigraphie von Deutschland V. Das Oberkarbon (Pennsylvanium) in Deutschland, ed. Deutsche Stratigraphische Kommission. Courier Forschungsinstitut Senckenberg 254: 255-270.

Kraus, O., and C. Brauckmann. 2003. Fossil giants and surviving dwarfs. Arthropleurida and Pselaphognatha (Atelocerata, Diplopoda): Characters, phylogenetic relationships and construction. Verhandlungen des Naturwissenschaftlichen Vereins in Hamburg, Neue Folge 40: 5-50.

Kukalová, J. 1969. Revisional study of the order Palaeodictyoptera in the Upper Carboniferous shales of Commentry, France. Part II. Psyche 76(4): 439-486.

Kukalová-Peck, J., and E.S. Richardson Jr. 1983. New Homoiopteridae (Insecta: Paleodictyoptera) with wing articulation from Upper Carboniferous strata of Mazon Creek, Illinois. Canadian Journal of Zoology 61: 1670-1687.

Leipner, A. 2019. A spectacular upper Carboniferous lake deposit from the Piesberg near Osnabrück (Lower Saxony, Germany). In Palaeoentomology meeting, Senckenberg Research Institute and Natural History Museum, Frankfurt am Main, October 2019. Abstract book, eds. M.M. Solórzano-Kraemer and S. Wedmann, 9.

Leipner, A., and P. Chellouche. 2019. A newly discovered lake deposit of Pennsylvanian age (upper Moscovian, Westphalian D) from the Piesberg Quarry. Osnabrück, Northwestern Germany. In 19th International Congress on the Carboniferous and Permian, Cologne, July 29-August 2, 2019, Abstracts, eds. S. Hartenfels, H.-G. Herbig, M.R.W. Amler, and M. Aretz. Kölner Forum Geologie und Paläontologie 23: 197-198.

Meunier, F. 1908. Nouveaux Paléodictyoptères du Stéphanien de Commentry. Bulletin du Museum National d'Histoire Naturelle, Paris 14: 34-36.

Meunier, F. 1910. Nouveaux Paléodictyoptères du houiller de Commentry. Bulletin du Museum National d'Histoire Naturelle, Paris 16: $233-237$.

Nel, A., P. Roques, P. Nel, A. Prokin, T. Bourgoin, J. Prokop, J. Szwedo, D. Azar, L. Desutter-Grandcolas, T. Wappler, R. Garrouste, D. Coty, D. Huang, M.S. Engel, and A.G. Kirejtshuk. 
2013. The earliest known holometabolous insects. Nature 503: 257-261. https://doi.org/10.1038/nature12629.

Pazinato, P.G., C. Haug, A. Leipner, J.T. Haug 2019. A new glimpse into the early diversification of peracarid crustaceans-An exceptionally preserved pygocephalomorph from the Upper Carboniferous of Germany. In Palaeoentomology meeting, Senckenberg Research Institute and Natural History Museum, Frankfurt am Main, October 2019. Abstract book, eds. M.M. Solórzano-Kraemer and S. Wedmann, 9.

Pecharová, M., N.D. Sinitshenkova, and J. Prokop. 2020. On the morphology of the Late Paleozoic insect families Bardohymenidae and Aspidothoracidae (Palaeodictyopterida: Megasecoptera). Arthropod Structure and Development 55: 100916.

Poschmann, M., and T. Schindler. 2004. Sitters and Grügelborn, two important Fossil-Lagerstaetten in the Rotliegend (? Late Carboniferous-Early Permian), with a description of a new palaeoniscoid (Osteichthyes, Actinopterygii). Neues Jahrbuch für Geologie und Paläontologie, Abhandlungen 232: 283-314.

Rößler, R. 1998. Arachniden-Neufunde im mitteleuropäischen Unterkarbon bis Perm-Beitrag zur Revision der Familie Aphantomartidae Petrunkevitch 1945 (Arachnida, Trigonotarbida). Paläontologische Zeitschrift 72: 67-88.

Schneider, J.W., S.G. Lucas, F. Scholze, S. Voigt, L. Marchetti, H. Klein, S. Opluštil, R. Werneburg, V.G. Golubev, J.E. Barrick, T. Nemyrovska, A. Ronchi, M.O. Day, V.V. Silantiev, R. Rößler, H. Saber, U. Linnemann, V. Zharinova, and S.-Z. Shen. 2019. Late Paleozoic-early Mesozoic continental biostratigraphy_Links to the standard chronostratigraphic scale. Palaeoworld. https://doi. org/10.1016/j.palwor.2019.09.001.

Sinitshenkova, N.D. 2002. Superorder Dictyoneuridea Handlirsch, 1906 (= Palaeodictyopteroidea). In History of insects, eds. A.P. Rasnitsyn and D.L.J. Quicke, 115-124. Dordrecht: Kluwer Academic Publishers.
Teixeira, C. 1941. Nouveaux insects du Stéphanien Portugais. Boletim da Sociedade Geológica de Portugal 1: 13-31.

Wrede, V., G. Drozdzewski, D. Juch, A. Leipner, and M. Sowiak. 2019. Field trip A2: The Pennsylvanian of the Ruhr Basin and Osnabrück region, western Germany-facies, stratigraphy and tectonics of a paralic foreland basin of the Variscides. In 19th International Congress on the Carboniferous and Permian, Cologne, July 29-August 2, 2019, Field guides, eds. H.-G. Herbig, M. Aretz, M.R.W. Amler, and S. Hartenfels. Kölner Forum Geologie und Paläontologie 24: 43-80.

Zessin, W. 2006. Zwei neue Insektenreste (Megasecoptera, Odonatoptera) aus dem Westfalium D des Piesberges bei Osnabrück, Deutschland. Virgo. Mitteilungsblatt des Entomologischen Vereins Mecklenburg 9(1): 37-45.

Zessin, W., C. Brauckmann, and A. Leipner. 2021. Sowiakala perprocera n. g. n. sp. (Sowiakalidae n. fam.) - eine neue interessante Libelle (Insecta: Odonatoptera: Prozygoptera) aus dem Westfalium D (Pennsylvanium, Oberkarbon) vom Piesberg bei Osnabrück. Clausthaler Geowissenschaften 11: 19-26.

Zessin, W., L. Koch, and C. Brauckmann. 2019. Bild- und Literaturdokumentation (1972 bis 2017) einer bedeutenden Fossil-Lagerstätte für Insekten u. a. Fossilien-die oberkarbonische Ziegeleigrube Hagen-Vorhalle, Nordrhein-Westfalen, Deutschland. Virgo. Mitteilungsblatt des Entomologischen Vereins Mecklenburg 22: 64-90. 